\title{
ASSESSMENT OF NATURAL VENTILATION SYSTEM FOR A TYPICAL RESIDENTIAL HOUSE IN POLAND
}

\author{
Romana ANTCZAK-JARZĄBSKA ${ }^{1}$, Marek KRZACZEK ${ }^{2}$ \\ Gdansk University of Technology, Gdańsk, Poland
}

\begin{abstract}
The paper presents the research results of field measurements campaign of natural ventilation performance and effectiveness in a residential building. The building is located in the microclimate whose parameters differ significantly in relation to a representative weather station. The measurement system recorded climate parameters and the physical variables characterizing the air flow in the rooms within 14 days of the winter season. The measurement results showed that in spite of proper design and construction of the ventilation system, unfavorable microclimatic conditions that differed from the predicted ones caused significant reduction in the efficiency of the ventilation system. Also, during some time periods, external climate conditions caused an opposite air flow direction in the vent inlets and outlets, leading to a significant deterioration of air quality and thermal comfort measured by $\mathrm{CO}_{2}$ concentration and PMV index in a residential area.
\end{abstract}

Keywords: natural ventilation, $\mathrm{CO}_{2}$ concentration, microclimate in living space, PMV, stack effect.

\section{INTRODUCTION}

The economic realities in Poland and building construction common practices over the years favor the cheapest ventilation systems which are natural ventilation. Recently, there is a growing interest in natural ventilation due to its

\footnotetext{
${ }^{1}$ Corresponding author: Gdansk University of Technology, Faculty of Civil and Environmental Engineering, Narutowicza st 11/12, 80-233 Gdańsk, Poland, e-mail: romana.antczak@pg.gda.pl

${ }^{2}$ Corresponding author: Gdansk University of Technology, Faculty of Civil and Environmental Engineering, Narutowicza st 11/12, 80-233 Gdańsk, Poland, e-mail: marek.krzaczek@wilis.pg.gda.pll
} 
passive nature and low energy consumption (Kleiven 2003). Study of (Krishan 2001) shown that natural ventilation has become a new trend in building design in architectural community. Furthermore, natural ventilation has been used in many types of buildings, even in highly indoor climate controlled hospitals (Clarke 2001). However, natural ventilation is difficult to design and control. In the chapter, the ventilation efficiency, indoor air quality and thermal comfort in the naturally ventilated building is discussed. The investigations are limited to residential house equipped with the natural, stacked ventilation system.

In natural stack ventilation, the air flow is created by stack effect and gusts of wind (Etheridge et al 1996, Mochida et al 2005, Santamouris et al 2006). In stack ventilation air is driven through the building by temperaturee differences developed by thermal buoyancy. The warm air inside the building is less dense than cooler air outside, and thus flows from openings in the envelope up to the chimneys ducts, while, cooler fresh air enters indoor zones. The process continues since the air entering the building is continuously heated, typically by casual or solar gains. The stack ventilation is not only driven by buoyancy forces, but also by wind-induced inertial forces. Since the same openings may contribute to both stack and wind pressure induced flows, they must not be considered in isolation (Etheridge 2011, Gratia et al 2004, Lau et al 2006). If the ambient air temperature equalizes with the internal air temperature, the stack effect decreases. Consequently, the buoyancy forces in ventilation ducts become too small to effectively remove waist air from the room. Natural, stacked ventilation is a commonly used principle when buildings are to be ventilated. The air flow can be controlled by active area of the operable openings in the building envelope and by an active area of the inlets to the chimneys ducts. It can also be simple adjusted by opening a door or a window to let the fresh air in (Steen Larsen 2006).

The air flow around the building's opaque can create areas with different values of dynamic temperature. This is due to aerodynamic impaired flow around the building. Air flow around the building creates areas of increased values of dynamic pressure on the facades in the direction normal to the air flow and areas of reduced dynamic pressure in the area of roof path. The differences in dynamic pressure between inlets and outlets of air cause air flow in rooms thereby providing access to fresh air ventilation. This mechanism forces air flow in rooms that is random and depend on incident climate conditions. However, a proper building geometry, the distribution of internal spaces and location of inlet and outlet openings can significantly improve efficiency of natural and stacked ventilation systems and extend periods of time in which the ventilation systems effectively remove waste air. The purpose of this article is to assess the impact of unfavorable microclimate parameters on the efficiency of ventilation systems, air quality and thermal comfort in the dwellings. Investigations of the 
indoor air flow characteristics and the external climate parameters were carried out using long-term measurements of basic physical variables. The measured variables characterized the properties of the external climate, the nature of the air flow in rooms and indoor climate parameters as well. Measurements of the physical variables characterizing the air flow in a building were perfomed in the apartment, which was located in the most inconvenient location of the building. In terms of ventilation system efficiency the location is poor because the apartment is located on the top floor of the building, just below the unheated and unused attic. During the measurement time period, the physical parameters characterizing the air exchange process were monitored. The research was conducted during the winter time, when temperatures differences between ambient and indoor air are the biggest and the stack effect is signifficant.

\section{CHARACTERISTICS OF THE REFERENCE BUILDING}

Long-term investigations were carried out in a residential, multifamily house, located in Gdańsk, northern Poland (Fig. 1). The test apartment was inhabited during the measurement campaign. The resident's activity was registered mainly in the morning and in the evening (after 5:00 pm). In the building, there are three stairways, four floors, a full basement with unused attic and only onestorey dwellings.

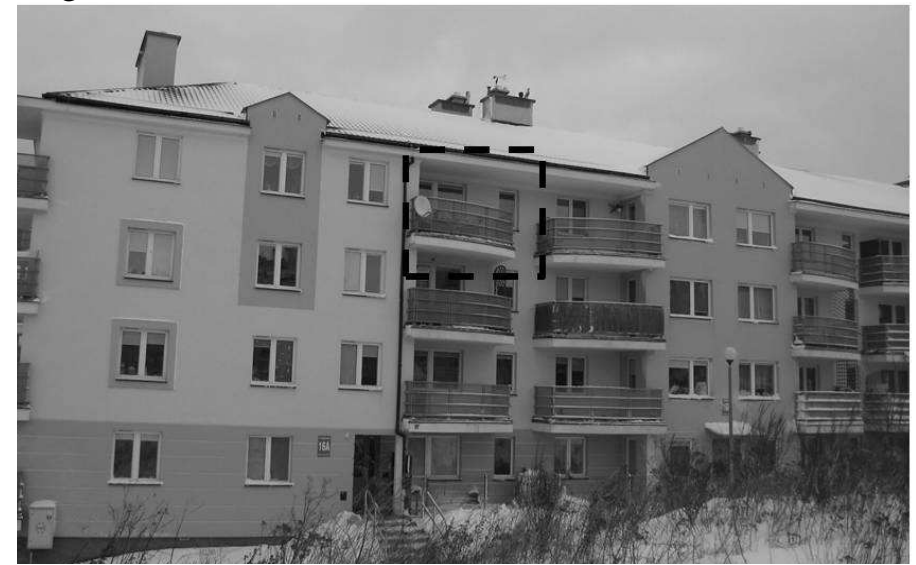

Fig. 1. Reference building in Gdańsk with the selected spot measurements (Foto by: R.Antczak-Jarząbska)

The building is made from prefabricated components, and the structural system is mixed. The height of the building from the entry level to the ridge is $14.60 \mathrm{~m}$. A double-sided apartment (including exterior walls oriented in two opposite geographical directions) located on the top floor in the middle of the building 
(Fig. 1) was selected. Over the test dwelling, there is an unused and unheated attic. As a thermal barrier of the last floor ceiling, the project adopted the thermal insulation layer separating the apartment from the unused attic, but not the roof surface. Consequently, almost the entire length of the outlet ducts of the ventilation system are passing through a space that is not heated and does not have contact with outside air (Fig. 2).

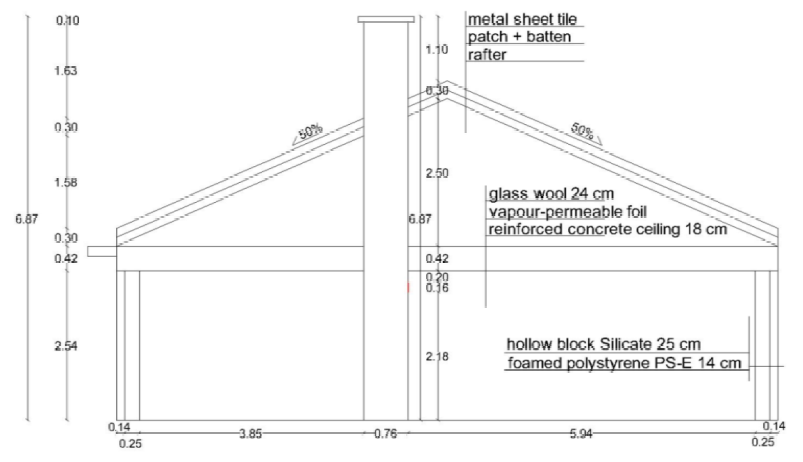

Fig. 2. Vertical corss-section through the attic above test apartment

The construction walls were made from silicate blocks $25 \mathrm{~cm}$ thickness and insulation of $14 \mathrm{~cm}$ thickness and ceiling from Filigran slabs of $20 \mathrm{~cm}$ thickness. The roof structure was made from wood components, roof surfaces are symmetrical with $26.5^{\circ}$ slope. The ventilation chimneys ducts were made from ceramic blocks $19 / 19 \mathrm{~cm}$ and a cross-section $\varnothing 15 \mathrm{~cm}$ extension on each floor. The transmission heat coefficient $\mathrm{U}$ was $0.25 \mathrm{~W} /\left(\mathrm{m}^{2} \mathrm{~K}\right)$ (external walls), $1.3 \mathrm{~W} /\left(\mathrm{m}^{2} \mathrm{~K}\right)$ (windows) and $0.22 \mathrm{~W} /\left(\mathrm{m}^{2} \mathrm{~K}\right)$ (roof).

\section{MEASUREMENT SETUP AND TEST EQUIPMENT}

The meaning of all symbols and denotations used in the formulae should be explained. To perform measurements, a number of sensors were used: LB-746 sensors to measure wind velocity and direction, LB-516A/AT hygrometer temperature and humidity logger, barometer LB-750 designed to measure the current barometric (hydrostatic) pressure, LB-801 anemometer with thermometer function designed to measure the air flow velocity and temperature, LB-854 $\mathrm{CO}_{2}$ sensor of the $\mathrm{CO}_{2}$ concentration in air primary function and additionally featuring as thermometer. All sensors had metrological properties confirmed. The sensors were connected to a data acquisition module. Data collected in the data acquisition module were automatically transferred to the SQL database, located on a PC computer. Schematic location of sensors in the apartment is shown in figure 3. Description of measured values and location of the sensors is presented in Tab. 1. The sensors were positioned to determine 
the effect of wind velocity and direction as well as the outside air temperature on the flow characteristics of the air in the rooms. Arrangements of the sensors were adapted to the expected flow profiles of air in the rooms. It enabled to identify the velocity and temperature of the air, flowing through the characteristic points of internal zones: the air flow through the window inlets, a door opening in the inner wall of the living room and the ventilation duct outlet in the bathroom. The outside climate parameters were measured in close proximity to the air ventilation inlet. The sensors location enabled to take into account the air inflow disturbances of the entering air mass on the facade of the building.

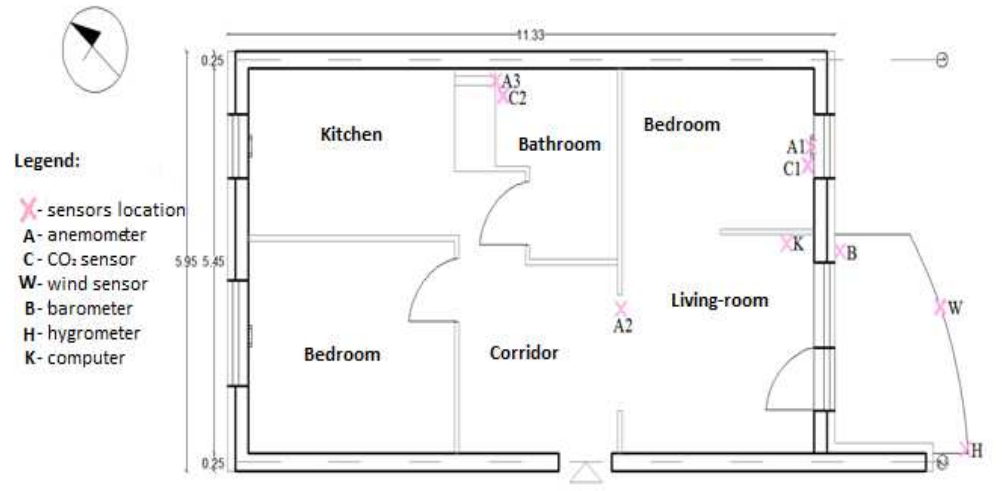

Fig. 3. Floor plan with the location of the sensors

Table 1. A description of the measurement sensors

\begin{tabular}{|c|c|c|c|}
\hline Symbol & Sensor name & Measure value & Sensor location description \\
\hline \multirow{2}{*}{ W } & Wind sensor & Velocity $[\mathrm{m} / \mathrm{s}]$ & \multirow{2}{*}{$\begin{array}{l}\text { A sensor located on the railing } \\
\text { of the balcony. Sensor located } \\
\text { parallel to the facade of the } \\
\text { building. }\end{array}$} \\
\hline & Wind sensor & Direction $\left[{ }^{\circ}\right]$ & \\
\hline \multirow{2}{*}{$\mathrm{H}$} & Hygrometer & Humidity [\%] & \multirow{2}{*}{$\begin{array}{l}\text { A sensor located on the railing } \\
\text { of the balcony. }\end{array}$} \\
\hline & Hygrometer & Temperature $\left[{ }^{\circ} \mathrm{C}\right]$ & \\
\hline B & Barometer & Pressure $[\mathrm{hPa}]$ & $\begin{array}{l}\text { A sensor located on the external } \\
\text { wall of the building. }\end{array}$ \\
\hline \multirow[b]{2}{*}{ A1 } & Anemometer & Velocity [m/s] & \multirow{2}{*}{$\begin{array}{l}\text { A sensor located in opening air } \\
\text { distribution in window in } \\
\text { bedroom. }\end{array}$} \\
\hline & Anemometer & Temperature $\left[{ }^{\circ} \mathrm{C}\right]$ & \\
\hline \multirow{2}{*}{ A2 } & Anemometer & Velocity [m/s] & \multirow{2}{*}{$\begin{array}{l}\text { A sensor located in a door } \\
\text { opening in the inner wall } \\
\text { between living room and } \\
\text { corridor. }\end{array}$} \\
\hline & Anemometer & Temperature $\left[{ }^{\circ} \mathrm{C}\right]$ & \\
\hline A3 & Anemometer & Velocity $[\mathrm{m} / \mathrm{s}]$ & A sensor located in the \\
\hline
\end{tabular}




\begin{tabular}{|l|l|l|l|}
\hline & Anemometer & Temperature $\left[{ }^{\circ} \mathrm{C}\right]$ & $\begin{array}{l}\text { ventilation duct outlet in the } \\
\text { bathroom. }\end{array}$ \\
\hline $\mathrm{C} 1$ & $\mathrm{CO}_{2}$ sensor & $\mathrm{CO}_{2}[\mathrm{ppm}]$ & $\begin{array}{l}\text { A sensor located at window in } \\
\text { bedroom about } 30 \mathrm{~cm} \text { from air } \\
\text { inlet. }\end{array}$ \\
\cline { 2 - 4 } & $\mathrm{CO}_{2}$ sensor & Temperature $\left[{ }^{\circ} \mathrm{C}\right]$ & $\begin{array}{l}\text { A sensor located in bathroom } \\
\text { about } 15 \mathrm{~cm} \text { from ventilation } \\
\text { duct. }\end{array}$ \\
\hline
\end{tabular}

The continuous measurement of physical values was performed within 14 days from $02 / 08 / 13$ to $02 / 22 / 13$. The sampling time was 60 second.

\section{RESULTS}

\section{External climate conditions}

The results of measurements of the local ambient microclimate were compared with the climate database of Typical Meteorological Year (TMY) (EN ISO 15927:4) of the meteorogical station in Gdańsk. The ambient air temperature, the wind velocity and direction were compared. A waveform diagram of the ambient temperature variations (Fig. 4) obtained from measurements indicates lower values than values in TMY, which are considered in the building energy demand simulations. On the basis of the existing regulations (PN-83/B-03430) in the design of stack ventilation, it is assumed that its nominal performance is to be obtained when the temperature difference between indoor and ambient air is higher than $12{ }^{\circ} \mathrm{C}$. With the ambient temperature decrease, air velocity in the chimney, and thus the performance of the ventilation system is to be increased.

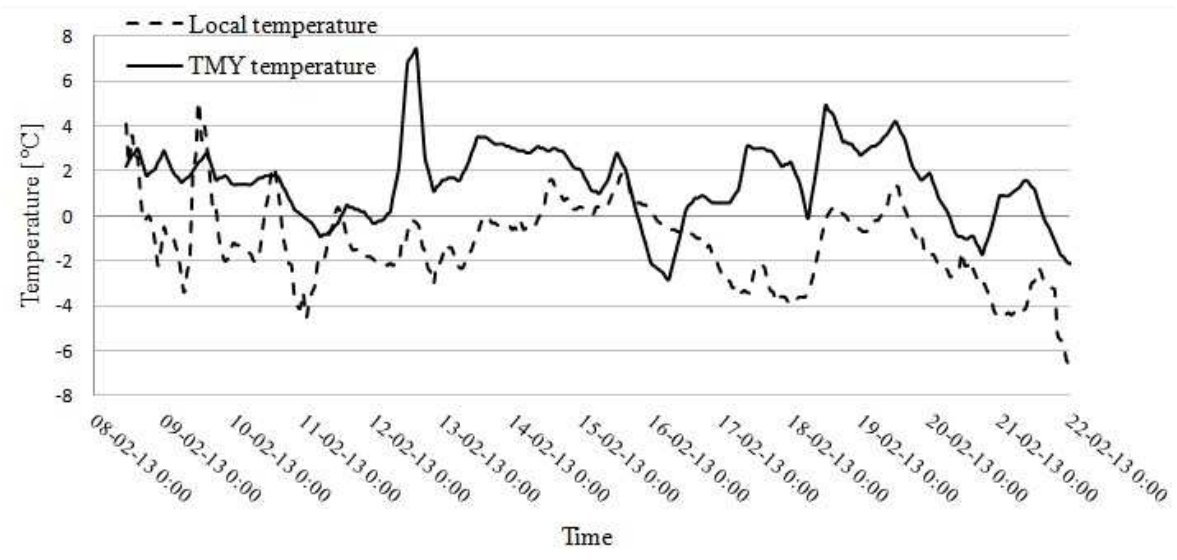

Fig. 4. Comparison of ambient air temperature variations according to TMY of representative meteorological station in Gdańsk with measured values 
However, wind gusts can influence the air flow patterns and characteristcs significantly. A magnitude of the wind velocity and its direction can increase the air exchange rate in the air inlet rapidly. The characteristic of the wind conditions in the test house location was made on the basis of TMY data. The meteorological stations are usually located in large open spaces, thus in many cases, it seems to be reasonable to adjust the data to a particular building location, e.g. in the middle of an urban area. For the test house, the corrected velocity profile is presented in figure 5 . Figure 5 shows the percentage of wind direction at the measurement site according to measured values and TMY data for Gdańsk. The dominant measured wind direction is north direction N (40\%), and then the north-east NE (15\%). With the lowest frequency wind blows from the east E (6\%) and south-east SE (3\%). However, for the TMY data, dominant direction during this time period is the north direction $\mathrm{N}(90 \%)$.

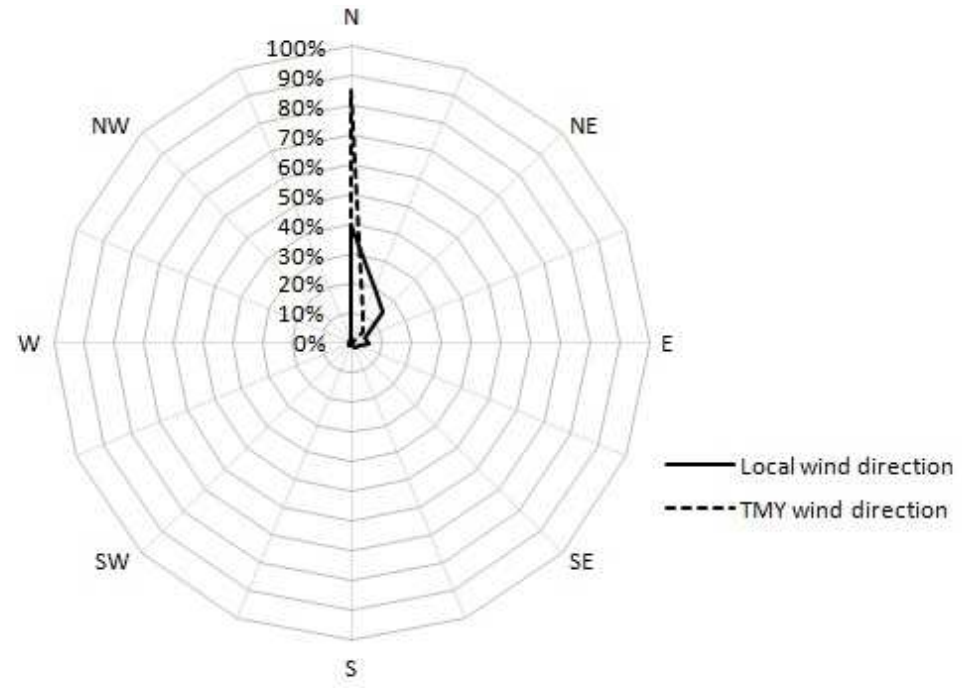

Fig. 5. Wind rose showing the average percentage of wind direction for a representative meteorological station and the measured values

The analysis of the wind velocity variations (Fig. 6), shows, that in urban area wind velocity is significantly reduced (by $50 \div 60 \%$ ) compared to undeveloped areas. The measured wind velocity variations show that a time period of silence $(0 \div 0.5 \mathrm{~m} / \mathrm{s})$ is $60 \%$ of the measurement duration. In the remaining time period, the wind velocity is very low $(0.5 \div 2 \mathrm{~m} / \mathrm{s})-20 \%$ or low $(2 \div 4 \mathrm{~m} / \mathrm{s})-20 \%$. It can be concluded, that the wind velocity decrease is caused by reduced in range ground-level thermal inversion, limiting the area available for vertical mixing. For long-term residual inversion layers, typical in the first half of a cold season, they can degrade significantly performance of natural ventilation system. 


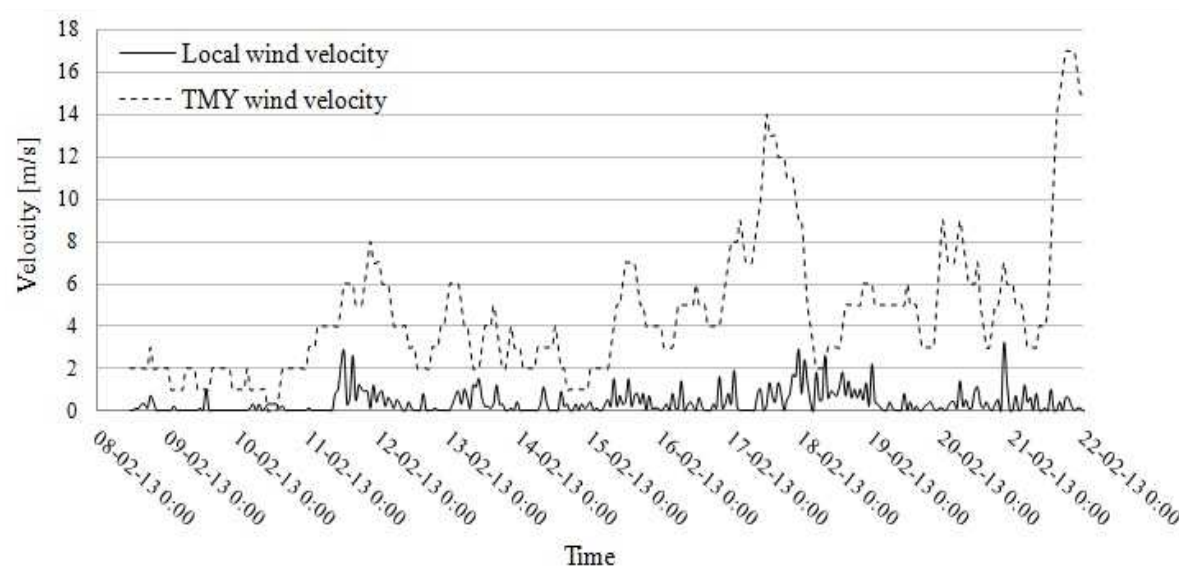

Fig. 6. Comparison of wind velocity variations between the TMY data and the measured values

\section{Efficiency of stack ventilation}

Efficency of natural ventilation was calculated on the basis of an approach proposed by Awbi 2003. The overall ventilation effectiveness for the temperature distribution $\bar{\varepsilon}_{\mathrm{t}}$ provides a quantitative index related to the way in which the heat is distributed inside the indoor zone. The higher value of $\bar{\varepsilon}_{\mathrm{t}}$ the more is the homogeneous temperature distribution. Following this approach, the overall ventilation effectiveness for the temperature distribution $\bar{\varepsilon}_{\mathrm{t}}$ is defined as:

$$
\bar{\varepsilon}_{\mathrm{t}}=\frac{\mathrm{T}_{\text {outlet }}-\mathrm{T}_{\text {inlet }}}{\mathrm{T}_{\text {average }}-\mathrm{T}_{\text {inlet }}}
$$

where:

$\mathrm{T}_{\text {outlet }} \quad-$ is the average temperature for the air- $\mathrm{CO}_{2}$ mixture at the outlet into the chimney duct, ${ }^{\circ} \mathrm{C}$

- is the average temperature for the air- $\mathrm{CO}_{2}$ mixture all over the breathing zone, ${ }^{\circ} \mathrm{C}$

- is the average temperature for the air- $\mathrm{CO}_{2}$ mixture at the inlet, ${ }^{\circ} \mathrm{C}$

The temperatures are calculated by the following equations:

$$
\begin{gathered}
\mathrm{T}_{\text {average }}=\frac{\mathrm{T}}{\mathrm{A}_{\mathrm{z}}} \\
\mathrm{T}_{\text {outlet }}=\frac{\mathrm{T}}{\mathrm{S}_{\mathrm{r}}}
\end{gathered}
$$




$$
\mathrm{T}_{\text {inlet }}=\frac{\mathrm{T}}{\mathrm{S}_{\mathrm{s}}}
$$

where:

$A_{z}$ - is the area of the breathing zone, $\mathrm{m}^{2}$

$\mathrm{S}_{\mathrm{r}}$ - is the outlet surface, $\mathrm{m}^{2}$

$\mathrm{S}_{\mathrm{S}}$ - is the inlet surface, $\mathrm{m}^{2}$

$\mathrm{T}$ - is temperature in point, ${ }^{\circ} \mathrm{C}$

The effectiveness calculations were based on the average daily air temperature for the time period of 14 days. Highest efficiency of the ventilation system is present in the range of 0 to 2 (Rim et al 2009). The values of the upper limit of the range mean higher ventilation performance. Analysis of the results (Fig. 7) indicates that most of the time efficiency of the ventilation system was at the desired level. Interesting are last two days, during which there is an unexpected and rapid change of the ventilation system performance. This unexpected change was caused by the rapid change in air inlet velocity (doubled magnitude) induced by the wind gust.

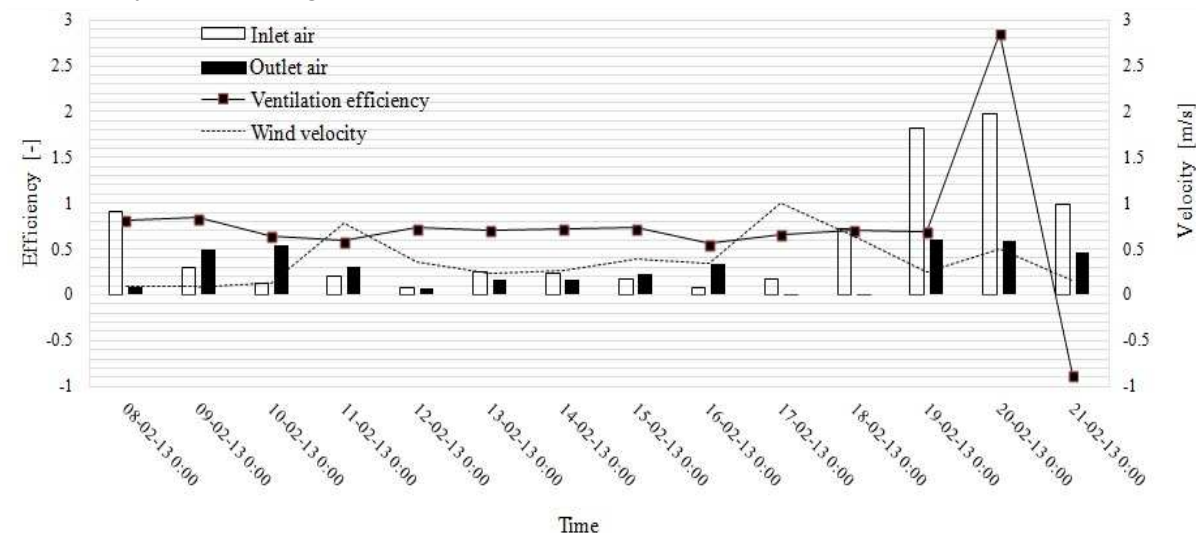

Fig. 7. Influence of wind velocity on air inlet and outlet velocities and on ventilation efficiency

Further results analysis shows periodic variations of air flow direction vent in outlet (Fig. 8 and Fig. 9). The results of measuremens of velocity and airflow direction (Fig. 8) in inlet in the window showed distinct relation between outside air temperature and airflow direction in the air inlet. The ambient air temperature increase above $0.2{ }^{\circ} \mathrm{C}$, in most cases, results reversal airflow direction in air inlet. The ambient air temperature $0.2{ }^{\circ} \mathrm{C}$ is too high to overcome hypertension in the air outlet to the chimney's duct and restore appropriate airflow direction from room to the ambient air. 


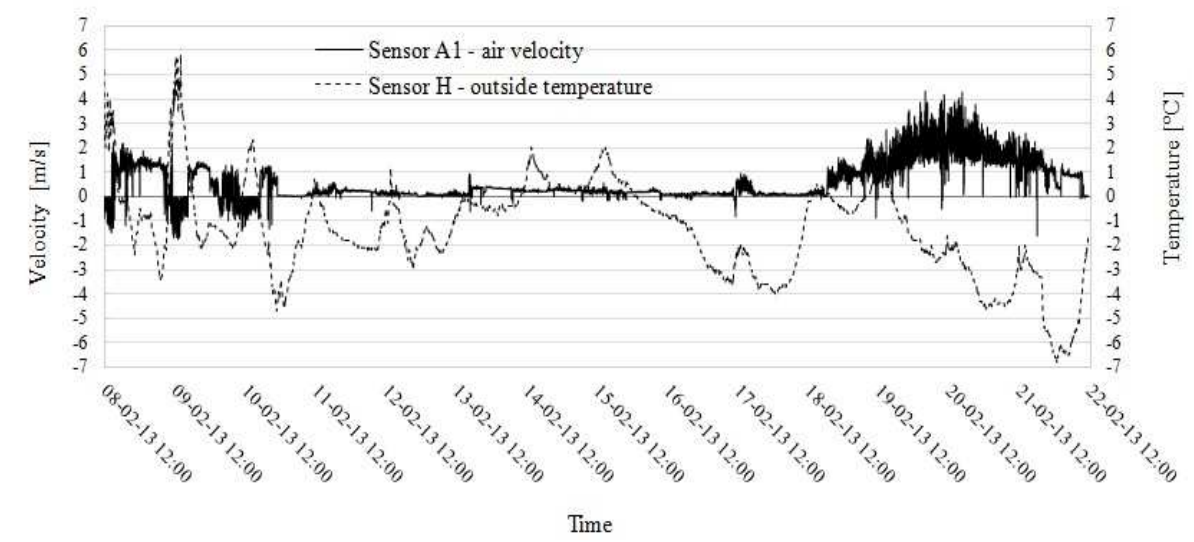

Fig. 8. Temperature variations of ambient air (sensor $\mathrm{H}$ ) and airflow velocity through air inlet in the window (sensor A1)

When comparing variations of air velocity in the chimney's duct in a bathroom with wind velocity outside the building (Fig. 9) it can be concluded that there is a strong relation between wind velocity and the air outletlet velocity to the chimney's duct. The higher wind velocity, the higher is velocity of air outlet to the chimney's duct in bathroom. The above mensioned relation confirms existing state of knowledge about the mechanisms that enforce airflow in natural (stack) ventilation. However, in certain periods of time in which the wind velocity decreases and declines to zero (Fig. 9), the ventilation system is going to improve the indoor climate conditions, what causes the reversed airflow. It is caused by significant local growth of dynamic pressure.

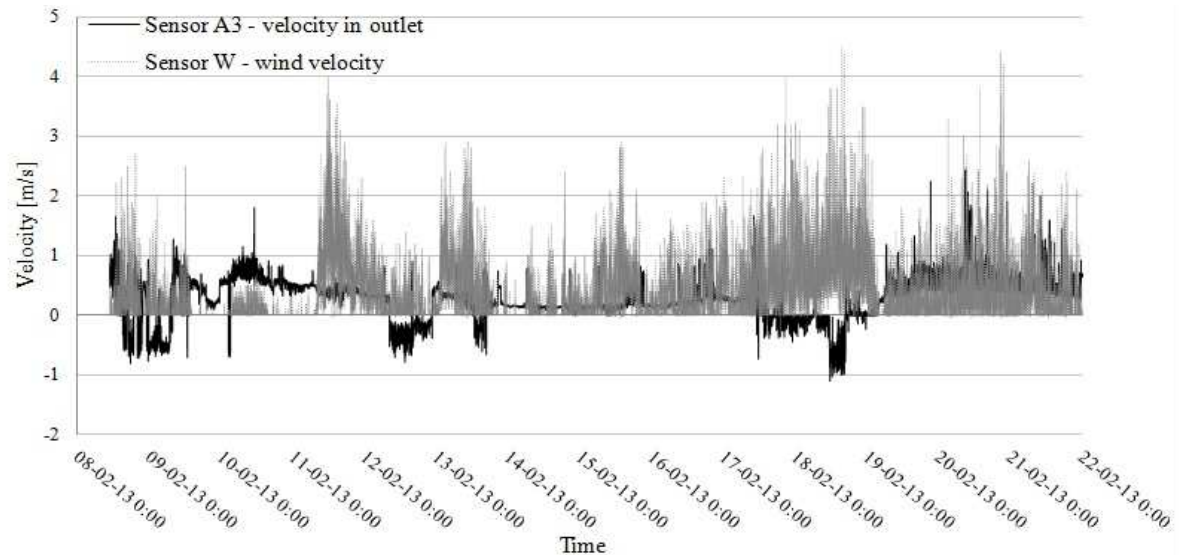

Fig. 9. Variations of wind velocity (sensor W) and air velocity in vent outlet in bathroom (sensor A3). Negative values of air outlet velocity (sensor A3) point at reversed airflow direction 


\section{Air quality in the apartment}

Investigations of all types of indoor air pollutants for the general air quality monitoring and assessment are complicated (Redlich et al. 1997). In many studies, it was suggested that the measurement and analysis of the indoor carbon dioxide $\left(\mathrm{CO}_{2}\right)$ concentration could be useful for understanding the indoor air quality and ventilation effectiveness. The results show that during the measurement time period, in the apartment dominated high concentration of $\mathrm{CO}_{2}$ in the air. Sensors recorded values of the concentration of carbon dioxide even above $3500 \mathrm{ppm}$ (Fig. 10). On the grounds of the Pettenkofer scale (accepted by World Health Organization) it can be stated that poor air quality relates to concentration $\mathrm{CO} 2$ in the air above $1000 \mathrm{ppm}$ (above background levels). The $\mathrm{CO}_{2}$ concentration above $2500 \mathrm{ppm}$ is dangerous for human health. In the paper, the $\mathrm{CO}_{2}$ concentration limit was defined as the sum of $1000 \mathrm{ppm}$ plus the background concentration, and equals of $1500 \mathrm{ppm}$. The recorded values excide the range of comfort and can cause a considerable discomfort feeling.

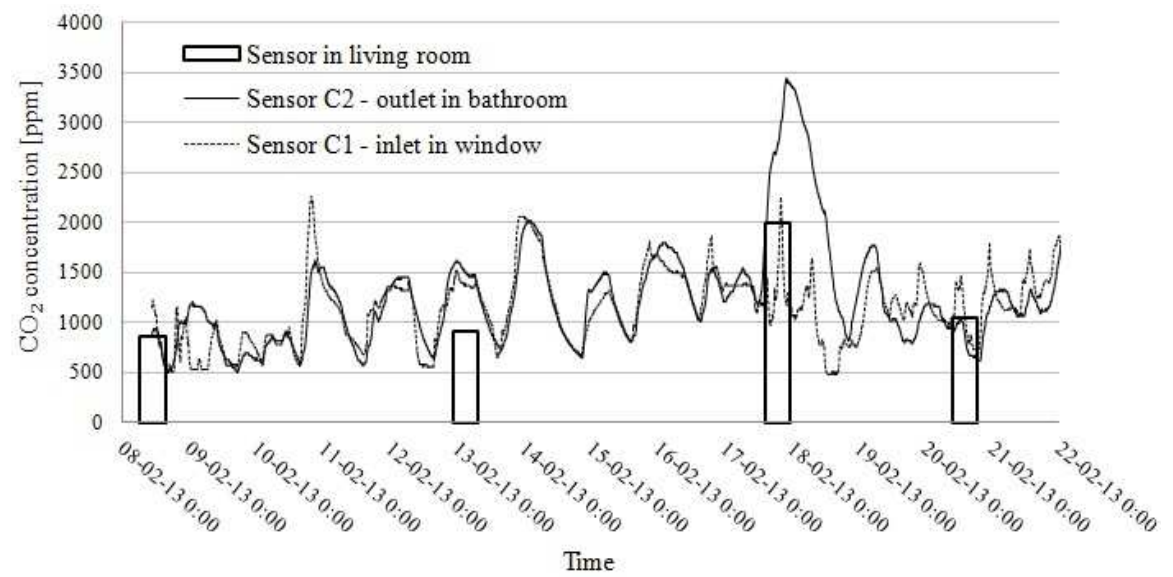

Fig. 10. Variations of $\mathrm{CO}_{2}$ concentration in the air outlet in the bathroom (sensor $\mathrm{C} 2$ ), in the air inlet in window (sensor $\mathrm{C} 1$ ) and temporary measurements in living room

Maintaining good indoor air quality depends on more than just providing adequate outside air and controlling indoor air pollutants. Minding the relative humidity of the air is just as important. Figure 11 shows the variations of the relative humidity of the ambient air. Besides continuous measurements of relative humidity of the ambient air, short time measurements of relative humidity of indoor air in the living room and bathroom were conducted. The results of short time measurements performed in the apartment in comparison with the long time results performed outside the building indicate low relative humidity of air in the apartment. In the performed experiments results by 
Tsutsumia et al (2006) the relative humidity in the apartment should be in the range from $35 \%$ to $60 \%$, what can maintain comfort conditions (Burek et al 2006). The measured values of indoor air relative humidity remained in the middle of the comfort range comfort.

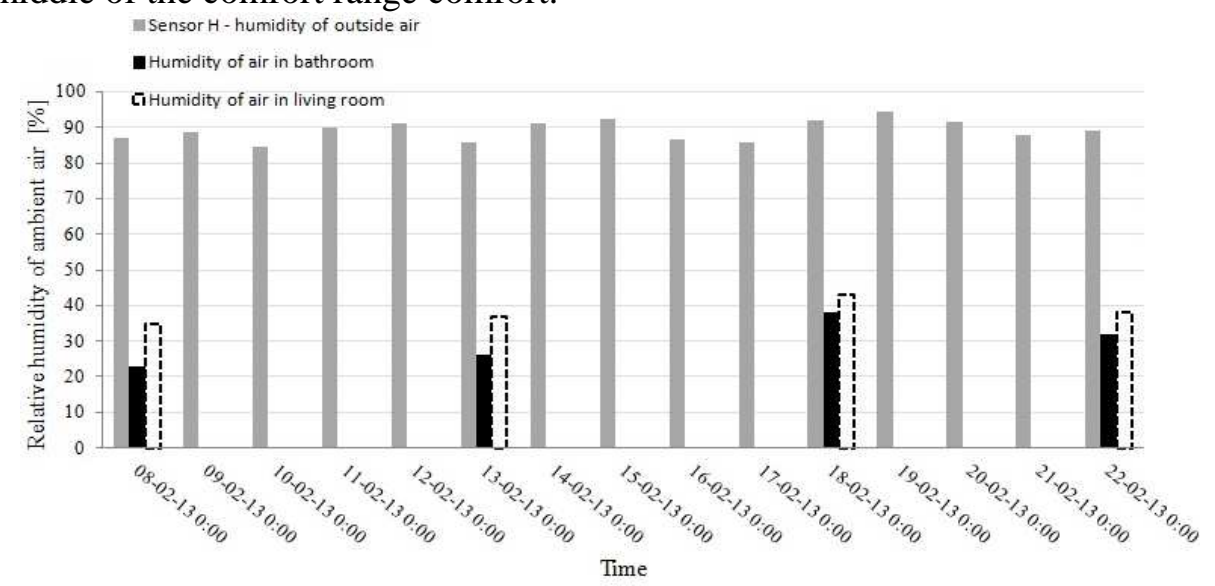

Fig. 11. Variations of relative humidity of ambient air and results of short time measurements of indoor air relative humidity measured in the living room and bathroom

The indoor air quality is investigated in terms of the ventilation effectiveness, which is based on the $\mathrm{CO}_{2}$ concentration in the breathing zone. The ventilation effectiveness $\eta_{\mathrm{v}}$ (Lawrence \& Braun 2007) is a measure of how the supply airflow mixes with the breathing zone for a removal of $\mathrm{CO}_{2}$ or other pollutants. In this case, the ventilation effectiveness $\eta_{\mathrm{v}}$ was calculated based on the concentration of $\mathrm{CO}_{2}$ :

$$
\eta_{\mathrm{v}}=\frac{\mathrm{c}_{\mathrm{r}}-\mathrm{c}_{\mathrm{s}}}{\mathrm{c}_{\mathrm{r}}-\mathrm{c}_{\mathrm{s}}}
$$

where:

$\mathrm{C}_{\mathrm{r}}$ - average $\mathrm{CO}_{2}$ return concentration, [ppm]

$\mathrm{C}_{\mathrm{s}}$ - average $\mathrm{CO}_{2}$ supply concentration, [ppm]

$\mathrm{C}_{\mathrm{z}}$ - average $\mathrm{CO}_{2}$ concentration in the breathing zone, [ppm]

The average $\mathrm{CO} 2$ concentrations $\mathrm{Cr}, \mathrm{Cz}$ and $\mathrm{Cs}$ are computed from:

$$
\begin{gathered}
\eta_{\mathrm{v}}=\frac{\mathrm{c}_{\mathrm{r}}-\mathrm{c}_{\mathrm{s}}}{\mathrm{c}_{\mathrm{r}}-\mathrm{c}_{\mathrm{s}}} \\
\mathrm{C}_{\mathrm{z}}=\frac{\mathrm{C}}{\mathrm{A}_{\mathrm{z}}}
\end{gathered}
$$




$$
\begin{aligned}
& \mathrm{C}_{\mathrm{r}}=\frac{\mathrm{C}}{\mathrm{S}_{\mathrm{r}}} \\
& \mathrm{C}_{\mathrm{s}}=\frac{\mathrm{C}}{\mathrm{S}_{\mathrm{s}}}
\end{aligned}
$$

The ventilation effectiveness which is a measure of how well the supply airflow mixes with the breathing zone for a removal of $\mathrm{CO}_{2}$ was calculated on temporary value (Fig.12). During this study return and supply concentration of $\mathrm{CO}_{2}$ were measured in long term average value, while concentration of $\mathrm{CO}_{2}$ in the breathing zone were made temporary measurements.

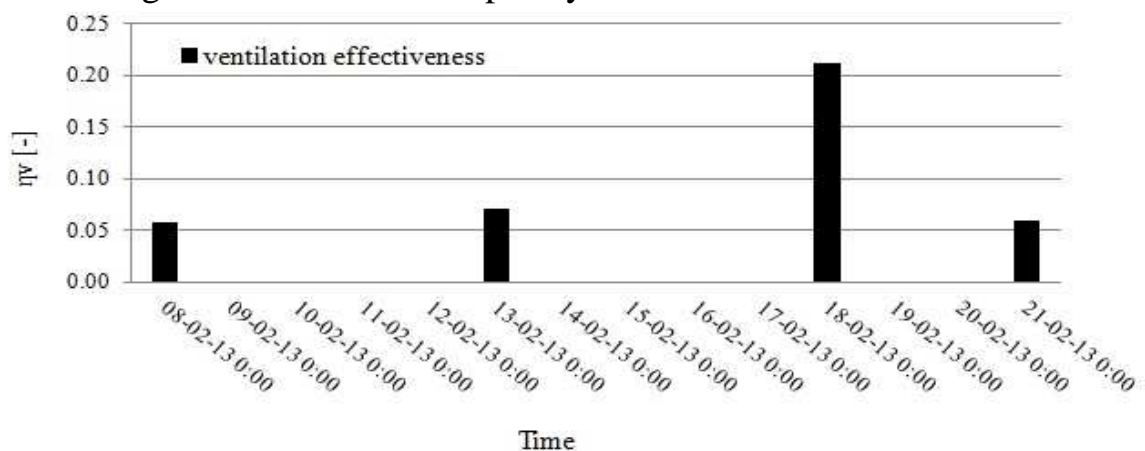

Fig. 12. The ventilation effectiveness in terms of $\eta_{\mathrm{v}}$ index

The overall ventilation effectiveness for a $\mathrm{CO}_{2}$ concentration is provided by the quantitative index $\eta_{\mathrm{v}}$ related to the way in which the polluted is distributed over the indoor zone. However, for all investigated cases, the $\eta_{v}$ index is almost the same (varies in the range of $(0.06-0.07)$ ). It means that a $\mathrm{CO}_{2}$ concentration is on enough level. The only exception is observed for the cases when $\mathrm{CO}_{2}$ was on high level, the $\eta_{v}$ index reaches 0.21 .

\section{THERMAL COMFORT}

Figures and tables should be included in the file with the main text. All figures should be clear, with concise and comprehensive captions, written as below. Concerning the problem of indoor air quality in residential houses it is reasonable to take into account the thermal comfort indices. In 1970s three the most significant thermal comfort models were developed: the Gagge's two-node model, the Fanger's PMV model and the Stolwijk's multinode model. These models enable to predict the human thermal comfort by assessing the net heat load on the human body. The most know is the Fanger's PMV model (Jones 2002), thus in this paper, the comfort PMV index is used. The model is derived from the physics of the heat exchange process using an empirical fit to the 
sensation (Fountain et al 1995). The model does not attempt to simulate transient conditions or thermal regulatory system (Jones 2002). Instead, the model evaluates a thermal strain under steady state conditions. The strain amount correlates with the total heat flux between the body and environment. Despite its steady state basis, the model is often used to evaluate transient but still close-to-steady conditions, like those met in most buildings. The PMV index represents the "predicted mean vote" (on the thermal sensation scale) of a large population of people exposed to a certain environment. The PMV is the expected comfort vote on the ASHRAE scale of the subjective thermal sensation (cold (-3), cool (-2), slightly cool (-1), neutral (0), slightly warm (1), warm (2), hot (3)) (Humphreys et al 2002).

The predicted mean vote (PMV) equation is as follows (ISO 7730:2005):

$$
\begin{aligned}
\mathrm{PMV}=[0.303 & \exp (-0.036 \mathrm{M})+0.028]\{(\mathrm{M}-\mathrm{W})-3.05 \\
& * 10^{-3}\left[5733-6.99(\mathrm{M}-\mathrm{W})-\mathrm{p}_{\mathrm{a}}\right] \\
& -0.42[(\mathrm{M}-\mathrm{W})-58.15]-1.7 * 10^{-5} \mathrm{M}\left(5867-\mathrm{p}_{\mathrm{a}}\right) \\
& -0.0014 \mathrm{M}\left(34-\mathrm{t}_{\mathrm{a}}\right)-3.96 \\
& \left.* 10^{-8} \mathrm{f}_{\mathrm{cl}}\left(\mathrm{t}_{\mathrm{cl}}+273\right)^{4}-\left(\mathrm{t}_{\mathrm{MR}}+273\right)^{4}\right] \\
& \left.-\mathrm{f}_{\mathrm{cl}} \mathrm{h}_{\mathrm{c}}\left(\mathrm{t}_{\mathrm{cl}}-\mathrm{t}_{\mathrm{a}}\right)\right\}
\end{aligned}
$$

where:

$\mathrm{W}$ - is the effective mechanical power [W/m2] (usually around 0),

Icl - is the clothing insulation [m2K/W],

pa - is the water vapor partial pressure $[\mathrm{Pa}]$,

ta $\quad$ is the air temperature $\left[{ }^{\circ} \mathrm{C}\right]$,

tMR - is the mean radiant temperature (MRT) $\left[{ }^{\circ} \mathrm{C}\right]$,

fcl - is the fraction of body clothed [-],

tcl - is the temperature of clothing surface $\left[{ }^{\circ} \mathrm{C}\right]$,

hc - is the convective heat transfer coefficient [W/(m2K)].

The clothing temperature tcl must be found by iteration from:

$$
\begin{aligned}
& \mathrm{t}_{\mathrm{cl}}=35.7-0.028(\mathrm{M}-\mathrm{W})-\mathrm{I}_{\mathrm{cl}}\{3.9 \\
& * 10^{-8} \mathrm{f}_{\mathrm{cl}}\left[\left(\mathrm{t}_{\mathrm{cl}}+273\right)^{4}-\left(\mathrm{t}_{\mathrm{MR}}+273\right)^{4}\right] \\
&\left.+\mathrm{f}_{\mathrm{cl}} \mathrm{h}_{\mathrm{c}}\left(\mathrm{t}_{\mathrm{cl}}-\mathrm{t}_{\mathrm{a}}\right)\right\}
\end{aligned}
$$

where $h_{c}$ is determined by:

$$
h c=\left\{\begin{array}{cl}
2.38 *\left|t_{\mathrm{cl}}-\mathrm{t}_{\mathrm{a}}\right|^{0.25} & \text { for } 2.38 *\left|\mathrm{t}_{\mathrm{cl}}-\mathrm{t}_{\mathrm{a}}\right|^{0.25}>12.1 \sqrt{\mathrm{V}_{\mathrm{ar}}} \\
12.1 \sqrt{\mathrm{V}_{\mathrm{ar}}} & \text { for } 2.38 *\left|\mathrm{t}_{\mathrm{cl}}-\mathrm{t}_{\mathrm{a}}\right|^{0.25}<12.1 \sqrt{\mathrm{V}_{\mathrm{ar}}}
\end{array}\right.
$$


And $\mathrm{V}_{\mathrm{ar}}$ stands for the relative air velocity [m/s]. The fraction of the body clothed fcl can be approximated using the following formula:

$$
f_{c l}= \begin{cases}1.00+1.290 I_{c l} & \text { for } I_{c l} \leq 0.078 \\ 1.05+0.645 I_{c l} & \text { for } I_{c l}>0.078\end{cases}
$$

The PMV is calculated from the following input parameters: clothing level, humidity, activity level, air temperature, air velocity magnitude and mean radiant temperature. In this work, the clothing level, humidity and activity level are assumed to be constant and equal to $1 \mathrm{~m}^{2} \mathrm{~K} / \mathrm{W}, 40 \%$ and 0.6 met, respectively. The air velocity and the temperature are hourly averaged during the simulation. The mean radiant temperature is assumed to be equal to the spatially hourly averaged indoor air temperature.

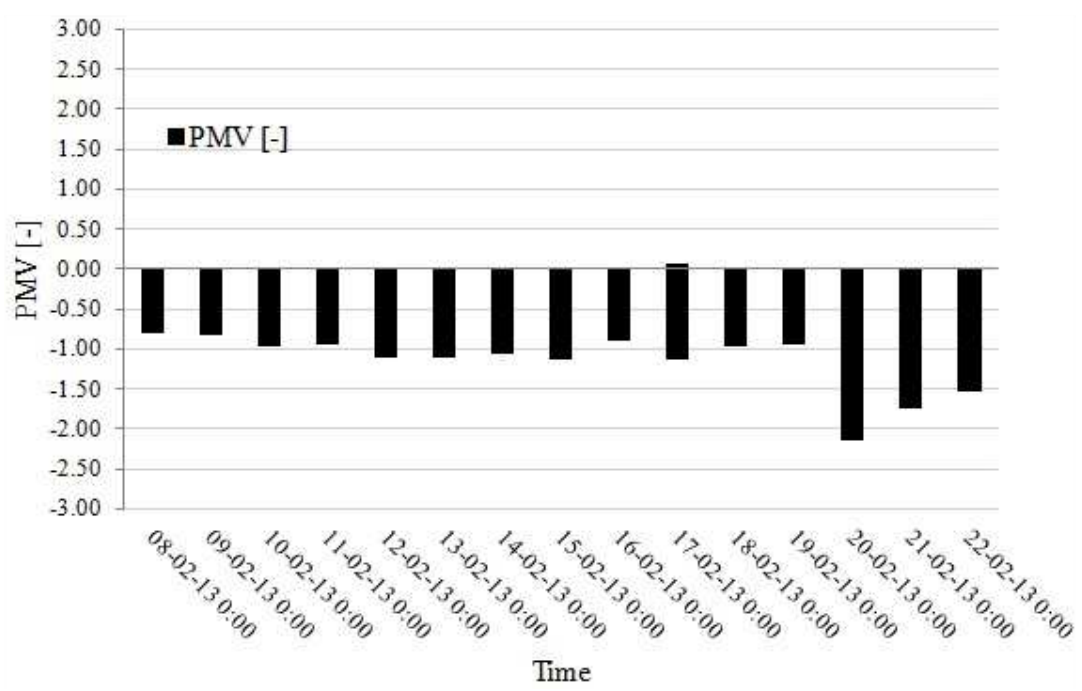

Fig. 13. The average PMV index for test apartment with natural ventilation

The measurements results showed that during the measurement time period, cool or slightly cool climate conditions dominated (Fig.12). The results are strongly dependent on the outdoor conditions. To fully evaluate the thermal comfort in buildings a much longer time period should be analyzed. On the other hand, such short time period ( 2 weeks) still provides interesting results. In the case of test apartment with natural ventilation, the thermal comfort is strongly dependent on wind velocity. Most of time, the thermal comfort was kept on satisfaction level (PMV= -1.0) (FIG.12), except last three days. According to the measurements results it can be concluded that the worst PMV index $(\mathrm{PMV}=-2.0)$ was obtained in the apartment during the windy days. 


\section{RESULTS DISCUSSION}

Natural, stack ventilation offers many benefits. Among the advantages of passive ventilation are (Martin et al 2000):

- Reduced operating costs

- Lower initial (construction) costs

- Decreased impact on the environment

- However, before natural ventilation can be widely adopted as a passive cooling and ventilation strategy, the underlying phenomena that govern the flow patterns and temperature distribution must be considered during design stage.

The ventilation system in the test apartment was designed according to the technical requirements: Regulation of the Minister of Infrastructure on technical conditions for buildings and location of buildings and PN-B-03430:1983 ventilation in residential houses and public buildings - Requirements. Even though, airflow direction reversed periodically at both the inlet and outlet of the ventilation system in the dwelling. The time intervals of airflow direction reversal were brief and landed in the outlet air in the bathroom of the apartment $13.6 \%$ of the measurement time period (46 hours) and in the window air inlet $7.8 \%$ of the measurement time period ( 26 hours). The effect of airflow direction reversal could be linked to low temperatures on the surface of the chimney's duct and partly to the unheated attic.

Our investigations demonstrate that during most of the measurement time period, the ventilation efficiency met standards requirements. Only, during two last days of measurements, the measurements show different results. It can be concluded that they are related to the low wind velocity and temperature difference between ambient and indoor. The observed decrease in wind velocity at the test house location is related to housing density and landform. It should be noted that during most of measurement time period, there were observed unfavourable weather conditions, and amongst others frequent calm winds $(60 \%)$. During the measurements time period, lower thermal inversions were observed, which hold mixing of ambient air.

The measurements results show that disturbed air flow in the ventilation system had significant influence on the high carbon dioxide concentration in the indoor air. The $\mathrm{CO}_{2}$ concentration in the indoor air, which reached magnitudes of 3500 ppm, could additionally endanger the health of residents. As a consequence, removal of waste air has stopped what resulted in the observed increase of $\mathrm{CO}_{2}$ concentration.

Carbon dioxide and air humidity are the most harmful components of comfort and air quality. The measurement results showe that $\mathrm{CO}_{2}$ concentration in the 
apartment significantly exceeded the limits. In contrast, the relative humidity of indoor air was at a low level. The low values of the relative humidity are related to high air exchange rate in the room and partly to resident's habits. It is supprising because usually low efficiency of ventilation system causes increase in the air humidity volume and $\mathrm{CO}_{2}$ concentration as well. However, the measurements results didn't show such a relationship. To study this phenomenon, more complex investigations are required.

The PMV model is proven to give more accurate results in the case of airconditioned buildings than naturally ventilated ones (Fanger et al 2002). It is found that the thermal comfort scale used with the PMV model is too strict for the natural ventilation. One of the reasons is that expectations upon the buildings are lower than upon the air-conditioned buildings. However, the PMV model is still used by researchers and engineers to predict the thermal comfort in naturally ventilated buildings (Ravikumar et al 2011), despite its potential inaccuracy.

\section{CONCLUSIONS}

The field measurements were carried out to study performance of the stack ventilation, the indoor air quality and thermal comfort in residential house. The measurements results show that housing density and form of land reduces the wind velocity, what results in decreased efficiency of natural ventilation in the residential houses. The high index of $\mathrm{CO}_{2}$ concentration in the breathing zone is related to air flow direction reversal in the vent inlets and outlets.

A problem of the thermal comfort and indoor air quality rises in buildings located in hilly areas with different local microclimate conditions. The problem concerns several storeys buildings, especially apartments on the top floors.

The thermal comfort strongly depends on weather conditions. Analyzing the measurements results, it can be observed that the natural ventilation in cold climate conditions and form of land cannot maintain the satisfying thermal comfort level.

The results confirm necessity to make measurements of local climate conditions in the planning phase.

The successful natural ventilation implementation in residential houses is to consider local climate conditions and perform optimization of the natural ventilation configuration at the early design stage. Natural ventilation can considerably improve air quality, making a significant contribution to better life in building.

Our further research will focus on experimental and numerical investigations of climate conditions and ventilation configuration influence on air quality in the breathing zone. 


\section{ACKNOWLEDGMENTS}

The present study was supported by the research project "Longlife Invest" (Baltic Sea Region Pro-gramme 2007-2013, INTERREG IVB, project \#106) part-financed by the European Union (Euro-pean Regional Development Fund).

\section{REFERENCES}

1. Awbi H. "Ventilation of building", E \& FN Spon, 2003.

2. Burek R, Połednik B, Raczkowski A. "Study of the relationship between the perceived air quality and the specific enthalpy of air polluted by people", Archiwum Ochrony Srodowiska 2006.

3. Chu CR, Chiu YH, Wang YW. "An experiment study of wind-driven cross ventilation in partitioned buildings", Energy and Buildings 2010; 42: 667673.

4. Clarke D., "A breath of fresh air", Hospital Development. 32(11), (2001): 13-17.

5. Etheridge D. "Natural Ventilation of Buildings: Theory, Measurement and Design", John Wiley\&Sons 2011.

6. Etheridge D, Sandberg M. "Building Ventilation: Theory and Measurement", John Wiley and Sons; 1996.

7. Fanger P, Toftum J,"Extension of the PMV model to non-airconditioned buildings in warm climates", Energy and Buildings 34 (2002).

8. Fountain $\mathrm{M}$, Huizenga $\mathrm{C}$, "A thermal sensation model for use by the engineering profession, Results of Cooperative Research Between ASHRAE and Environmental Analytics", ASHRAE RP-781 Final Report, Piedmont, 1995.

9. Gratia E, Bruyere I, De Herde A. "How to use natural ventilation to cool narrow office buildings", Building and Environment 2004; 39: 1157-1170.

10. Humphreys M, Nicol J, "The validity of ISO-PMV for predicting comfort votes in every-day thermal environments", Energy and Buildings 34 (2002).

11. Jones BW, "Capabilities and limitations of thermal models for use in thermal comfort standards", Energy and Buildings 34 (2002).

12. Kleiven T. "Natural Ventilation in Buildings. Architectural concepts, consequences and possibilities", Thesis submitted in partial fulfilment of the requirements for the degree of Doktor at Norwegian University of Science and Technology Faculty of Architecture and Fine Art Department of Architectural Design, History and Technology, 2003.

13. Krishan A., "Climate responsive architecture: a design handbook for energy efficient buildings", Tata McGraw-Hill Pub. Co., New York, 2001. 
14. Lau J, Chen Q. "Energy analysis for workshops with floor-supply displacement ventilation under the U.S. climates", Energy and Buildings 2006; 38: 1212-1219.

15. Martin, A. and J. Fitzsimmons. "Making Natural Ventilation Work". Guidance Note GN 7/2000. BSRIA, 2000.

16. Mochida A, Yoshino H, Takeda T, Kakegawa T, Miyauchi S. "Methods for controlling airflow in and around a building under cross ventilation to improve indoor thermal comfort", Journal of Wind Engineering and Industrial Aerodynamics 2005; 93: 437-449.

17. Ravikumar P, Prakash D, "Analysis of thermal comfort in a residential room with insect proof screen: A case study by numerical simulation methods", Building Simulation 4 (2011).

18. Redlich C., "Sick-building syndrome", Sparer J \& Cullen M. R. (1997).

19. Regulation of the Minister of Infrastructure dated 12.04.2002 on technical conditions for buildings and location of buildings.

20. Regulation of the Minister of Infrastructure dated 13.02.2003 on technical conditions for buildings and location of buildings.

21. Regulation of the Minister of Infrastructure dated 07.04.2004 on technical conditions for buildings and location of buildings.

22. Regulation of the Minister of Infrastructure dated 12.03.2009 on technical conditions for buildings and location of buildings.

23. Rim D, Novoselac A. "Ventilation effectiveness as an indicator of occupant exposure to particles from indoor sources", Building and Environment, 2009.

24. Santamouris M, Wouters P. "Building Ventilation: The state of the art", Earthscan; 2006.

25. Steen Larsen T, "Natural Ventilation Driven by Wind and Temperature Difference", PhD Thesis defended public at Aalborg University 020206, 2006.

26. Tsutsumia H, Tanabea S, Harigayaa J, Iguchib Y, Nakamura G. "Effect of humidity on human comfort and productivity after step changes from warm and humid environment", Building and Environment, 2006

27. PN-B-03430:1983. Ventilation in residential houses and public buildings Requirements.

28. EN ISO 15927-4. Hygrothermal performance of buildings - Calculation and presentation of climatic data - Part 4 Data for assessing the annual energy for cooling and heating systems.

29. ISO 7730:2005, Ergonomics of the thermal environment - Analytical determination and interpretation of thermal comfort using calculation of the PMV and PPD indices and local thermal comfort criteria, International Organization for Standarization, Geneva, 2005. 


\section{OCENA DZIAŁANIA WENTYLACJI NATURALNEJ W BUDYNKU MIESZKALNYM, WIELORODZINNYM}

\section{Streszczenie}

W artykule przedstawiono wyniki badań działania wentylacji naturalnej w budynku mieszkalnym, wielorodzinnym. Badanie przeprowadzone było w sezonie zimowym i obejmowało pomiar parametrów klimatu zewnętrznego i wielkości fizycznych charakteryzujących przepływ powietrza w pomieszczeniach. Wyniki pomiarów wykazały, że pomimo prawidłowego projektowania i budowy systemu wentylacji naturalnej w budynkach, niekorzystne warunki mikroklimatyczne, które różnią się od tych przewidywanych, spowodowały znaczne obniżenie wydajności systemu wentylacyjnego. Ponadto $\mathrm{w}$ artykule przedstawiono wpływ warunków klimatu zewnętrznego, na jakość powietrza w mieszkaniu. W badaniach wyznaczono komfort cieplny za pomocą indeksu PMV.

Słowa kluczowe: wentylacja naturalna, komfort cieplny, PMV, efekt kominowy.

Editor received the manuscript: 06.09.2015 